\title{
Work Ability Implication and Organization Climate Against Turnover Intention Through Job Satisfaction as Intervening Variables in Global Capital Investama, Palembang PT.
}

\author{
Afrizawati $^{1, *}$ Paisali $^{1}$ Divianto $^{1}$ Yahya $^{1}$ \\ ${ }^{1}$ Business Administration, State Polytechnic of Sriwijaya, Palembang, Indonesia \\ *Corresponding author.Email: afrizawati@polsri.ac.id
}

\begin{abstract}
This research raised the problems of how the implication of work ability and organizational climate on turnover intention and job satisfaction. Does work ability and organizational climate has a direct effect on turnover intention variables, as well as organizational climate and job satisfaction variables has a direct effect on job satisfaction, or can they also have an indirect effect, namely through turnover intention variables first, then job satisfaction variable for employees at Global Kapital Investama, Palembang PT. However, the results showed that work ability has a significant effect on job satisfaction, the effect of work ability on job satisfaction is significant with a magnitude $=$ 0.000 and a coefficient value of 1.028. and then job satisfaction on turn over intention is significant because the significance value of $t$ is smaller than 0.05 , which is equal to 0.000 . The coefficient value of 0.540 means that an increase in job satisfaction will increase the turn over intention of the employees of PT.GK Invest Palembang office by 0.540 . Meanwhile The direct effect of job satisfaction on turn over intention is significant with the significance which is the coefficient value of 0.540 means that an increase in job satisfaction will increase the turn over intention of the employees of PT.GK Invest Palembang office by 0.540 .
\end{abstract}

Keywords: work implication, organization climate, turnover intention, job satisfaction.

\section{INTRODUCTION}

Human resourcers is one of the important factors in a company in order to survive. Human resources are the main element in a company when compared to capital, technology, and money, because human resource plays a role in controlling the company's activities. If the company does not have adequate human resources, the company will not be able to develop properly. Good HR managers of companies need Human Resource Management (HRM). HRM are a program of activities carried out to obtain, develop and utilize human resources to support company goals.

One of the factors One of the factors that affect employee performance is the employee's work ability. Work ability relates to knowledge, talents, interests

and experiences in order to be able to complete tasks that are in accordance with the work they occupy. The management of the company must be able to develop the capabilities of each employee to suit the company's needs, because the ability to show the potential of an employee in doing their jobs.

The intense competition will encourage companies to improve employee capabilities, so that the products produced can compete in the market. In addition, companies need to know and meet the needs of each employee, so that employees can work optimally. Fulfilling this need are an effort to motivate employees to be more active and active at work.

In relation to human resources and organizational climate, from various studies that had been carried out, changes in organizational environmental conditions both internally and externally can directly or indirectly affect the organizational climate which is can reduce the level of job satisfaction so that it can lead to the intention to move employees (turnover intention) which in turn can lead to actual turnover. Various definitions of turnover intention are 
expressed by researchers. Turnover intention according to Cotton \& Tuttle [1] is defined as an estimate of the likelihood that an individual will remain in an organization.

In connection with the emergence of turnover intention, employees who has job satisfication will be more productive, contribute to organizational goals and objectives. Which is generally has a low desire to leave the company [2]. Turnover can be fatal for teh organization because it experiences a shortage of experts in the labor market and causes high ducational costs for novice employees [3]. Reseach conducted by [4] shows that sales force turnover is a major factor in business.

PT. Global Kapital Investama futures with trademark "GKFX" is an official futures brokerage company shere this reseach will be carried out, headquatered in Jakarta and regulated by BAPEBBTI and an official member of JFX and ICDX with a futures Brokerage Bussiness license No. 824 / BAPPEBTI / SI / II / 2005, Participant Approval SPA 1218 / BAPPEBTI / SP / 5/2007 Members of the Jakarta Futures Exchange (JFX) SPAB-103 / BBJ / 12/04 and members of the Indonesian Derivatives Clearing House (IDCH) $54 /$ AK- KBI / I / 2007. GK Invest is a member of the Indonesian Commodity \& Derivatives Exchange (ICDX) 057 / SPKB / ICDX / Dir / XII / 2011 and a member of the Indonesia Clearing House (ICH) 037 / SPKK / ISI-MTB / II / 2002.

Based on the observation of researchers, the work ability and organiztion climate in the company GK Invest Palembang is considered good enough, this is expected to continue to increase so that job satisfaction will be created which in the future will improve the performance of employees. The existing organizational climate is felt to be able to be built to provide things that can satisfy employees, and there is no more embarrassment and fear of employees in having opinions or disagreeing with leaders so that it can improve employee performance. Likewise with the ability of employees at work where the abilities of the employees already have good abilities.

Its is necessary to further socialize the goals or vision and mission of PT. Global capital Investama so that employees can clearly understand it. What is the organizational climate in PT. GK Invest can provide job satisfaction which in turn will improve the performance of its employees. According to the researcher, it is interesting to study and it is hoped that the results of this study can provide benefits for the development of PT. Global Investama in the future.

According, from the background, as well as the increasing number of similar organizations that are growing so as to increase the climate of competition between organizations, it is interesting to conduct research that examines the effect of organizational climate on job satisfaction and performance. This is what encourages researchers to conduct this research with the title "Implications of Work Ability and Organizational Climate on Turnover Intention through Job Satisfaction as an Interverning Variable at PT. Global Kapital Investama Palembang.

\section{LITERATURE REVIEW}

\subsection{Work Ability}

Ability is a person's ability which includes intelligence and skills in solving the problems it faces [5]. Ability to work shows a person's skills such as intelligence and skills. Ability is closely related to the physical and mental abilities people have to carry out work. [6] explains that "Ability is the capacity of an individual in carrying out his job duties". [7] describes "the ability to be a determining factor for the success of the personnel department to maintain effective human resources". Individuals who are unable to solve the problems they face will be conyysidered not serious in doing their work.

Ability is an up to date assesment Ability is an up-to-date assessment of what a person can do. The overall ability of an individual basically consists of two groups of factors: 1. Intellectual ability (Intellectual ability) Intellectual ability is the ability needed to perform various mental activities-thinking, reasoning and solving problems. Individuals in most societies place intelligence as a benchmark and intelligence is seen from the higher level of education 2. Physical abilities Physical abilities are the ability to perform tasks that require similar stamina, skills, strength and characteristics [8]. According to [9], individual abilities are influenced by the person's talents, interests and personality factors.

Measuring the ability of employees can be through: 1. The level of non-formal education that has been taken 2 . The level of work experience they have. 3 . The level of desire / willingness / interest of staff towards science and its development. Based on this opinion, it can be concluded that the ability of employees is one of the elements in maturity related to knowledge or skills that can be obtained from education, training and experience.

\subsection{Organization Climate}

Each organization or company has its way of presenting its business. Therefore, an organization has a different climate from other organizations. Climate can be oppressive, neutral or can also be supportive, depending on the part governing it, therefore every organization always has a unique work climate. Organizations tend to attract and retain people according to their climate so that to some degree the pattern can be 
lasting. To better understand the organizational climate the following will be explained in terms of organizational iklmi according to several experts, including:

According to [10], organizational climate is "the perception of members of the organization (individually and in groups) and those who are constantly in contact with the organization (eg suppliers, consumers, consultants and contractors) about what is or happens in the internal environment of the organization as a whole. routine, which influences the attitude and behavior of the organization and the performance of members of the organization which then determines the performance of the organization ".

Luthans in [11] states that organization climate is "Internal environment or organization psychology. Organization climate influences HR practices and policies accepted by members of the organization. Please note that each organization will have a different organization climate. The diversity of jobs designed within the organization or the nature of the individuals that exist will illustrate these differences

\section{The factors was Influenced Organization Climate}

[12] suggested that: "the factors that influence the organizational climate are work ethic, work discipline, satisfaction, communication and stress and conflict in organizations." This was made clear by [13], that to measure climate organization can be seen through the difference between the existing climate and the expected climate. There are 7 dimensions carried out in an effort to measure the organizational climate, which are as follows:

1. Conformity, if many organizations have rules that must be obeyed by workers even though these rules have no relevance or relation to the implementation of work.

2. Responsibility, if every decision taken in an organization is carried out by the leadership, the organization is said to have a low organization climate, because basically subordinates are not given the opportunity to participate in the organization.

3. In return, every activity carried out and getting good results or achievements does not get any award from the company otherwise if done wrong then the employees are given severe penalties, such a work climate is called a work climate with low rewards.

4. Group spirit, if in the organization people are suspicious of each other and it is difficult to trust and there is no group feeling then this work climate is called low work morale.

5. Clarity, an organization has unclear work procedures, people feel they do not know for sure which responsibilities and authorities.
6. Standards, stipulations about the quality of the work done by members.

7. Leadership, to create an effective organization there needs to be an organizational climate that includes high employee expectations, a positive attitude, an organized curriculum and employee reward and intensive systems.

According to [14] in this study the organizational climate indicators studied included: autonomy and flexibility, trust and openness, sympathetic and giving support, respecting honesty, clarity of purpose, risky work.

\subsection{Turnover Intention}

Turnover intention is a tendency to leave or quit a job or organization. Turnover intention is a description of thoughts of leaving or the desire to leave and look for work elsewhere. Turnover generally occurs in companies, industries, and the world of education [15]. Turnover intention occurs in employees aged 1852 years [16]. [17] stated in his research that young employees have a higher turnover rate.

[18] states that turnover intention can materially harm the organization, for example, financial and non-material expenditures, such as a decrease in production and neglect of work that should take a long time to complete. [19] in their research found that turnover intention resulted in financial losses and also disrupted organizational continuity. The same thing is also expressed by Law [20], [21] which states that the impact caused by turnover intention is material losses such as organizational expenses used to recruit new employees and reduce organizational production and work that is not finished because vacant position.

Turnover intention is a deliberate desire to leave a worker or company and organization that is considered the last decision in the withdrawal cognition sequence [22]. Turnover intention is the intention or even the tendency for someone to move or leave a job or company on the basis of their own choice and have the possibility to move from one workplace to another in accordance with the expectations they have for their job. [23] states that turnover intention contains aspects such as thoughts of leaving the company or withdrawing from the company while comparing what has been achieved in the previous company or organization with what has been obtained by friends in different companies. Another aspect is the intention to find another job and the intention to leave the company or organization after ensuring that he will quit the job or organization. 


\subsection{Job Satisfaction}

Herzberg, et.al [24] suggested that the term job satisfaction can be defined as a positive feeling which is the result of an evaluation of its characteristics. Job satisfaction is an individual thing. Each individual has a different level of satisfaction, as defined by [25], that job satisfaction as effectiveness or emotional response to various aspects of work. This definition implies that job satisfaction is not a single concept, on the contrary a person can be relatively satisfied with an aspect of his work and not satisfied with one or several other aspects. Herzberg also believes that there are four factors that affect one's job satisfaction, namely: Psychological Factors, Social Factors, Physical Factors, and Financial Factors.

Based on the opinion of [26], the indicators of job satisfaction can be divided into:

1. Salary or wages, i.e. the amount of payment a person receives as a result of carrying out work, is appropriate to the needs and is felt to be fair.

2. The work itself, that is the content of the work carried out by someone, does it have satisfying or unsatisfactory elements.

3. Co-workers, ie friends to whom someone always interacts in the implementation of work. Someone can feel that his co-workers are very pleasant or unpleasant.

4. Superiors or leaders, that is someone who always gives orders or instructions in carrying out work. Policies that are run by superiors can be unpleasant or pleasing to someone and this can affect job satisfaction.

5. Promotion or opportunity to advance, that is the possibility that someone can develop through promotion. A person can feel that there is a high possibility of promotion or not, the promotion process is open or not open. This can also be affect the level of job satisfaction of a person / individual.

\subsection{Empirical Review}

Work ability and organizational climate are very important topics as one of the determinants in the process of developing human resources in organizations. From various studies that have been conducted by experts in this field, it is evident that work ability and organizational climate have a huge influence on increasing job satisfaction and employee performance in a company as a whole.

Previous studies have shown that work ability can be a benchmark in doing a job where the impact is the maximum level of completing the job, while organizational climate has a type of organization related to job satisfaction components. In a study of non-profit employees, [27] found that a "friendly" organizational climate is associated with higher levels of job satisfaction with employees, and that the means and authority and tasks that lead to certain types of climate have a negative effect on overall job satisfaction. satisfaction with promotions, co-workers and supervisors.

Another study on organizational climate was also conducted by [28] using multivariate and univariate analysis techniques (Manova and Anova). In this study it was found that groups that differ from one another will have climatic climates that tend to be different. Job satisfaction is one of the most concepts in management literature, which counts more than 5000 literature that describes it [29]. The information that will be obtained through this research will have practical implications for individual and organizational performance in the same way. According to [30], employees want to get the best quality of life, both for themselves and their families, therefore understanding the level of job satisfaction and orientation is not only expected but also a critical or important aspect of life for individuals and organizations.

The relationship between organizational climate (professionalism, caring, rules, instrumental, efficiency, and independent) with the level of job satisfaction (pay, promoters, coworkers, supervisors and work itself) and performance in non-profit organizations has also been investigated by [31]. With a sample size of 252 middlelevel managers with an average age of 37 years and work experience for 11 years, it was found that none of the types of organizations had a significant effect on satisfaction with pay. This indicates that an organization can influence all aspects of job satisfaction and performance by applying organizational ethics, except for satisfaction with pay.

\section{ANALISYS}

\subsection{Job ability (X1) has a significant effect on job satisfaction (X3) variables.}

Based on inferential statistical analysis using path analysis or multiple linear regression analysis which is standardized, the first hypothesis states that work ability has a significant effect on job satisfaction, the results are proven and the hypothesis is an accepted. the effect of work ability on job satisfaction is significant with a magnitude $=0.000$ and a coefficient value of 1.028

The factors that cause the significance of work ability on job satisfaction are due to, among others, autonomy and flexibility in using a number of existing resources to support their work as employees in brokerage firms. So that there is a desire in the staff of education personnel to use a number of available resources and facilities. The employees at the GK Invest Palembang office have a good level of work ability, so that when there are demands in terms of achieving 
targets, employees are able to achieve them even by using all available abilities.

The main effect on the majority of employees who experience job satisfaction with work ability is when the leader assigns tasks according to the employee performance mapping. If the level of work ability is felt according to their expectations, then they will be satisfied and vice versa. Availability of facilities, communication flows that support in terms of quantity and quality, practice of decision-making in line at all levels, and on the other hand the welfare of employees still cannot be properly considered, will result in low job satisfaction.

The direct effect of organizational climate on job satisfaction is significant because the significance value of $t$ is greater than 0.05 , which is 0.671 . This results in a significant organizational climate on job satisfaction. With the responsibility that is owned by each employee, it can foster a sense of belonging in each employee. This condition further provides a high level of awareness of the meaning of the success of each task or job that is borne by employees in accordance with their respective job descriptions. In the minds of employees will be planted that the success of the company is also the success of the employees too. This will spur employee morale to always be successful in every activity so that in the end employees will feel satisfied with the results achieved.

\subsection{The Effect of Job Satisfaction Variables (X2) on Turn Over Intention (X4).}

The direct effect of job satisfaction on turn over intention is significant because the significance value of $\mathrm{t}$ is smaller than 0.05 , which is equal to 0.000 . The coefficient value of 0.540 means that an increase in job satisfaction will increase the turn over intention of the employees of PT.GK Invest Palembang office by 0.540 . Apart from being influenced by work ability, turnover intention of company employees can also be influenced by other factors outside of this study.

This means that job satisfaction is obtained because the work is done in accordance with the expertise, opportunities to attend education and training and promotions. This supports research from Samsi (2006) which states that employees who feel job satisfaction and feel happy will be motivated to increase the quality and quantity of their work. The high level of employee job satisfaction has a significant and positive effect on their performance.

\section{RESEACH RESULTS IMPLICATION}

For PT. GK Invest Palembang office based on the results of research that has been conducted, there are several things to consider. To improve the work ability of employees, the company PT. GK Invest Palembang office, must give recognition in terms of level of work, bonuses, high rebates for marketing and other welfare. Office facilities must also support, in addition to a conducive organizational climate, there are no significant problems between the marketing team, which can increase the satisfaction and work ability of employees in the brokerage company.

Apart from that, other factors besides those identified in this study must be found by conducting further research, either through quantitative or qualitative research. The results of this study give rise to a phenomenon that attracts all variables to influence each other, especially the turnover intention variable. Which even though the results are significant but can trigger the desire of employees to move from one division to another division team.

In the company PT. Global Kapital Investama Palembang office may not have detected that there is a desire from employees to move or leave the company. it is better for the company to be more solid in improving the abilities of employees so that job satisfaction can be maximally fulfilled. work. This will reduce their desire to try to move to another place. However, if they feel more valued and needed, for example involved in decision making and given credit for their contribution, then this will have a better impact on employee performance.

\section{CONCLUSION}

After testing using the path analysis technique it can be concluded:

1. Job ability variables significantly influence job satisfaction.

2. Organizational climate variables significantly influence effect on job satisfaction.

3. Job satisfaction variables significantly influence turnover intention variables.

According from discussion of the results of the study and the conclusions presented previously, the following suggestions can be made: The factors that lead significant job ability on job satisfaction include autonomy and solutions in using a number of existing resources to support their work as employees in a futures firm. So that there is a desire in employees to use a number of available resources and facilities. With the responsibility that is owned by each employee, it can foster a sense of belonging in each employee.

This condition further provides a high level of awareness of the meaning of the success of each task or job that is borne by employees in accordance with their respective job descriptions. In the minds of employees will be planted that the success of the company is also the success of the employees too. This will spur 
employee morale to always be successful in every activity so that in the end employees will feel satisfied with the results achieved.

Apart from being influenced by work ability, turnover intention of company employees can also be influenced by other factors in the above variables. This means that job satisfaction is obtained because the work is done according to expertise, in the form of opportunities to attend training and job promotions, such as marketing from $\mathrm{BDO}$ to become a supervisor.

\section{REFERENCES}

[1] Cotton, J and Tuttle, J (1986). Employee turnover: A meta-analysis and review with implication for research. Academy of Management Review, 11 (1), 55-70.

[2] Harter, Schmidt \& Hayes, 2002. Management of Organizational Behavior: Utilizing Human Resources. Four Edition. Terjemahan Oleh Agus Dharma: Manajemen Perilaku Organisasi: Pendayagunaan Sumber daya Manusia, Erlangga. Jakarta.

[3] Igbaria M. \& Greenhaus, J. H. (1992). Determinants of MIS employees turnover intentions: a structural equation model. Communications of the ACM, 35, pp. 34-51.

[4] [Mulki et al. (2006). Effect of ethical climate andsupervisory trust on Andi Caezar To Tadampali, dkk 46 / Jurnal Administrasi Publik, Volume 6 No. 2 Thn. 2016.Vol.XXVI, No.1, Winter, pp.19-26.

[5] [Wursanto, I.G. 2003. Dasar-Dasar Perilaku Organisasi.Yogyakarta : Andi

[6] Robbins, Stephen P. 2008. Perilaku Organisasi: Konsep, Kontroversi Aplikasi Jilid I dan II. Edisi Indonesia, PT. Prenhallindo. Jakarta.

[7] Handoko, T. Hani. 1998, Manajemen Personalia dan Sumber Daya Manusia. Edisi Kedua, Cetakan Kedua Belas, Yogyakarta: BPFE.

[8] Robbins, Stephen P. 1996. Perilaku Organisasi: Konsep, Kontroversi Aplikasi Jilid I dan II. Edisi Indonesia, PT. Prenhallindo. Jakarta.

[9] Mathis, R.L. \& J.H. Jackson. 2006. Human Resource Management: Manajemen Sumber Daya Manusia. Terjemahan Dian Angelia. Jakarta: Salemba Empat.
[10] Wirawan. (2006). Budaya dan Iklim Organisasi Teori Aplikasi dan Penelitian. Jakarta: Salemba Empat.

[11]Luthans,F 1995 Organizational Behavior, International Edition, McGraw Hill Book Co. Singapore.

[12] Anarogo dan Widianti. 2006. Psikologi dalam Perusahaan. Jakarta: Rineka Cipta.

[13] Kurniawati, Nia. (2006). Pengaruh Iklim Organisasi Terhadap Kepuasan Kerja Pegawai di Pusat Pendidikan dan Latihan Geologi. Bandung: Adpend FIP UPI, Skripsi tdak diterbitkan.

[14] Malhotra, Naresh, 1995. Marketing an Aplied Orientation, Prentice Hall International Edition, New York.

[15] Panggabean, Mutiara S. 2004, Manajemen Sumber Daya Manusia. Cetakan Kedua. Jakarta: Ghalia Indonesia.

[16][Rivai, Veithzal. 2004. Manajemen Sumber Daya Manusia untuk Perusahaan dari teori ke Praktik. Jakarta: RajaGRafindo Persada.

[17]Medina, E. (2012). Job satisfaction and employee turnover intention: what does organizational culture have to do with it. Columbia University, 1-44 https://doi.org/10.1093/jopart/mum013.

[18] Setyawan, Donny. (2005). Analisis FaktorFaktor yang Mempengaruhi Kepuasan Kerja dan Relevansinya terhadap Komitmen Organisasi (Studi Kasus Pada Pemkab Temanggung). Tesis. Semarang: Universitas Diponegoro.

[19] Khattak, J. D., \& Ahmad. (2017). Buying Meat for Family in the Collectivist Culture: An Application of the Theory of Planned Behavior. NUML International Journal of Business \& Management ISSN 2410-5392, 12(1), 145-163

[20] Singarimbun, Masri dan Sofian Effendi. 1995. Metode Penelitian Survey. Cetakan Kedua. Jakarta: LP3ES.

[21][Hussain, I., Arif, M. and Hussain, J. (2012) Fluoride Contamination in Drinking Water in Rural Habitations of Central Rajasthan, India. Environmental Monitoring and Assessment, $184,5151-5158$.

[22]Bothma, F. Chris dan Roodt, Gert. (2012). Work-Based identity and work engagement as potential antecedents of task performance and 
turnover intention: Unravelling a complex relationship. SA. Journal of Industrial Psychology, 38, 1-17.

[23] Mobley, William H. 1977. Intermediate Linkages in the Relationship between job satisfaction and employee turnover. Journal of Applied Psychology, 62, 237-240.

[24] Wirawan. (2006). Budaya dan Iklim Organisasi Teori Aplikasi dan Penelitian. Jakarta: Salemba Empat.

[25] Malhotra, Naresh, 1995. Marketing an Aplied Orientation, Prentice Hall International Edition, New York.

[26] Gibson, James L, Jhon M, Ivancevich dan James H. Donnelly JR. 1996. Organisasi dan Manajemen: Prilaku, Struktur, Proses, Edisi Ke Empat, Terjemahan, Penerbit Binarupa, Erlangga, Jakarta.
[27] Deshpande, S.P. 1996. The Impact of Ethical Climate type on facets of job satisfaction. Journal of Business Ethics. 15. 655-660.

[28] Payne, Partisson, 2007. Pemasaran Jasa. Terjemahan Fandi Tjiptono. Andi, Jakarta.

[29] Gibson, James L, Jhon M, Ivancevich dan James H. Donnelly JR. 2006. Organisasi dan Manajemen: Prilaku, Struktur, Proses, Edisi Ke Empat, Terjemahan, Penerbit Binarupa, Erlangga, Jakarta.

[30]Deshpande, S.P. 1996. The Impact of Ethical Climate type on facets of job satisfaction. Journal Of Business Ethics. 15. 655-660.

[31] Koh, H.C. \& Boo, \& Boo, E.H.Y. 2001. The link Beetwen Organizational Ethics and Job Satisfaction: A Study of Managers in Singapore. Journal Of Business Ethics 29:309324. 